\title{
EL CABILDO CATEDRALICIO DE LIMA CONTRA EL PÁRROCO ALONSO DE HUERTA POR LAS RENTAS ECLESIÁSTICAS (1592-1606)*
}

\author{
ALEXANDRE COELLO DE LA ROSA \\ Universitat Pompeu Fabra (UPF) ${ }^{\mathrm{a}}$
}

\begin{abstract}
RESUMEN
El objetivo de este trabajo es reconstruir las tensiones políticas entre una oligarquía eclesiástica local, centrada en el Cabildo metropolitano, y el segundo arzobispo de Lima, Toribio Alfonso de Mogrovejo (1538-1606), y el párroco Alonso de Huerta, uno de sus más fieles colaboradores. Aunque el Cabildo era una especie de senado o consejo permanente al servicio del clero diocesano, en ningún momento actuó como una institución de apoyo a la labor evangélica del Arzobispo Mogrovejo. Muy al contrario, sus miembros cerraron filas contra lo que consideraron una violación de sus privilegios económicos, y en numerosas ocasiones denunciaron al Arzobispo y al párroco Alonso de Huerta por considerar que se entrometían en el fuero interno del Cabildo.
\end{abstract}

Palabras clave: cabildo catedralicio, Alonso de Huerta, rentas eclesiásticas, Toribio Alfonso de Mogrovejo

\section{ABSTRACT}

The aim of this contribution is the presentation of the political conflicts between the Archbishop of Lima, Toribio Alfonso de Mogrovejo (1538-1606), together with

\footnotetext{
* Agradezco a Alejandra Rojas, a Patricia Pou i Vila y a Juan Carlos Garavaglia su ayuda y sus valiosos comentarios para la elaboración de este trabajo.

a Departament d'Humanitats, Facultat d'Humanitats. Ramon Trias Fargas 25-27, 08005 Barcelona. alex.coello@upf.edu ; acoello30@yahoo.com
} 
his faithful collaborator the parish priest Alonso de Huerta, and the cathedral chapter. Though the chapter was a sort of senate or permanent council of the diocese clergy, it by no means acted as an institution involved in the missionary commitments of Archbishop Mogrovejo. On the contrary, its members rallied around against what they considered to be a violation of their economic privileges, and on several instances they denounced the Archbishop, as well as the parish priest Alonso de Huerta, arguing that they intruded in the internal rules of the chapter.

Keywords: cathedral chapter, Alonso de Huerta, church rents, Torobio Alfonso de Mogrovejo

JEL Classification: N, N4, N46, N9, N96

\section{TORIBIO ALFONSO DE MOGROVEJO FRENTE AL CABILDO ECLESIÁSTICO DE LIMA}

Hace años, Enrique Dussel llamó la atención sobre la importancia de las relaciones entre el episcopado y el Cabildo metropolitano para la historia eclesiástica del Perú1. Si exceptuamos los trabajos de Pedro Guivobich Pérez, el interés de los investigadores por analizar una de las instituciones de mayor importancia en la historia colonial peruana ha sido más bien escaso ${ }^{2}$. En este estudio vamos a tratar de reconstruir las tensiones políticas que hubo entre el segundo arzobispo de Lima, Toribio Alfonso de Mogrovejo, y los prebendados del Cabildo eclesiástico. La historiografía colonial se ha centrado mayormente en la figura del Arzobispo, ensalzando sus virtudes como santo limosnero y visitador incansable de las tierras andinas ${ }^{3}$. Su objetivo no era otro que evangelizar a los indios del Perú a través de su experiencia misional, y a este fin dedicó la mayor parte de su tiempo, visitando continuamente una diócesis que abarcaba más de seis millones de kilómetros cuadrados ${ }^{4}$. Dichas visitas debían realizarse cada dos años y, al concluir, el monarca exigía una relación detallada que le informara de la situación económica, moral y espiritual de la diócesis.

A finales del siglo xvi, la Iglesia no podía ser contemplada de forma independiente de la esfera política. No sólo no se pensaba en separar la esfera política de

\footnotetext{
${ }^{1}$ Enrique D. Dussel (1969) y (1983).

${ }^{2}$ Para el siglo xvir, Pedro Guibovich (1994) ha estudiado las tensas relaciones entre el obispo Manuel de Mollinedo y el Cabildo eclesiástico del Cuzco (1673-1699). A juicio del historiador peruano, los canónigos desempeñaron un papel determinante en lo que resultó ser una lucha sin cuartel por el control del poder político y económico del obispado cuzqueño.

${ }^{3}$ Antonio de León Pinelo (1653), pp. 185-206; Antonio de Lorea (1679); Francisco Haroldo (1680); Echave y Assu (1688).

${ }^{4}$ Mary M. McGlone (1991), pp. 5-6.
} 
la religiosa, sino que la conexión entre ellas fue mucho más fuerte después de Trento que en ningún período anterior. Felipe in esperaba reforzar su poder soberano en Indias a través de los códigos conceptuales y estéticos de lo que José Antonio Maravall definió como la «cultura del Barroco». Se trataba de un proyecto expansionista en lo político y cultural, que buscaba unificar a todos los súbditos del Imperio en torno a un rey, un Dios y una lengua. Pero ello no significaba que la Monarquía -o el Estado, como apunta Maravall- y la Iglesia estuvieran unidas, sino que la Monarquía extendiera su dominio sobre la vida religiosa y la organización eclesiástica, haciendo del monarca la cabeza visible de la misma ${ }^{5}$.

No hay duda de que se equivocó. Nombrado arzobispo por el Papa Gregorio XIII, Toribio no estaba dispuesto a aceptar la nacionalización y estatalización de la Iglesia, sino a aplicar los postulados del Concilio de Trento en el Perú. Para ello se convirtió en un misionero de signo lascasiano cuya primera obligación consistió en ejercer de pastor de sus feligreses, ya fueran españoles o indios, durante más de veinte años ${ }^{6}$ Nada ni nadie le hizo cambiar de opinión. Su libertad e independencia eclesiástica contradecían los intereses de la Monarquía y sus burócratas en Indias, preocupados por acrecentar la Hacienda Real y la suya propia. Algunos virreyes, como Don García Hurtado de Mendoza, recomendaron incluso su sustitución, enfrentándose al prelado por defender a ultranza los intereses del clero secular frente a los regulares y la Compañía de Jesús.

Pero Toribio no estaba solo al frente del arzobispado. El Cabildo era la máxima autoridad del clero diocesano y actuaba como una especie de senado o consejo permanente a su servicio ${ }^{7}$. Entre sus principales funciones estaban las de favorecer las labores apostólicas y organizar la liturgia de la catedral. El 17 de septiembre de 1543, el arzobispo Jerónimo Loayza firmó el Acta de Erección de la Catedral de Lima y, autorizado por el Papa, eligió a los miembros de su Cabildo sin previa presentación del monarca ${ }^{8}$. Sin embargo, en los inicios del gobierno de Toribio, este organismo estaba todavía en proceso de formación. En la Memoria que envió en 1598 al Papa Sixto v decía que en la catedral había dieciséis canónigos y algunos de los cargos sólo existían nominalmente ${ }^{9}$. Cinco eran las dignidades: el deán, Don Pedro Muñiz de Carvajal, se encargaba del oficio y el culto divino y presidía el Cabildo; el arcediano, Don Bartolomé Martínez, era el responsable de

\footnotetext{
${ }^{5}$ José Antonio Maravall (1972), p. 234, y (1975).

${ }^{6}$ McGlone (1991), pp. 1-7 y 255-256.

${ }^{7}$ Antonio Ybot (1962), pp. 202; Rubén Vargas Ugarte (1959), pp. 166.

${ }^{8}$ Como los diezmos eran escasos, Loayza suspendió provisionalmente muchos de los oficios. Los miembros del Cabildo fueron el arcediano Francisco de León, el chantre Francisco de Ávila y los canónigos Alonso Pulido y Juan Lozano. Vid. Vargas Ugarte (1959), tomo I, pp. 162, y tomo II, pp. 169.

${ }^{9}$ Carlos García Irigoyen (1906), tomo II, pp. 238-254; José Dammert Bellido (1996), p. 250 .
} 
examinar a los candidatos al sacerdocio, visitar las diócesis en sustitución del Arzobispo y, en general, de supervisar las actividades pastorales; el chantre, Don Esteban Fernández Vosmediano, estaba encargado de la música del coro y del culto litúrgico; el maestrescuela, Don Mateo González de Paz, enseñaba gramática latina a los clérigos y predicaba en la catedral, y Cristóbal Medel, tesorero, tenía a su cargo los gastos del cabildo, los diezmos y el inventario de los bienes de la catedral. No hay que olvidar que al Cabildo se le asignaba una cuarta parte de los 104.683 pesos ensayados percibidos en concepto de diezmos por la Iglesia de Lima a principios del siglo XVII ${ }^{10}$. Además de estas dignidades había diez canónigos, cuatro de los cuales eran de oposición -ectoral, o teólogo del cabildo; magistral, encargado del púlpito; doctoral o asesor jurídico, y penitenciario- y seis de gracia o merced. Por debajo de los canónigos se situaban seis racioneros o beneficiados -el primero, Don Diego Ávila, nombrado en 1593-, que debían cantar pasiones, seis medio racioneros, encargados de cantar epístolas en el altar y en coro, seis capellanes, seis acólitos, dos curas y sacristán, un mayordomo y secretario, así como algunos oficiales, como el organista, el pertiguero, y el perrero ${ }^{11}$.

Las relaciones que Toribio mantuvo con el Cabildo fueron siempre tensas, y sus frecuentes ausencias dejaban a sus miembros como responsables de la continuidad de la labor pastoral. A menudo las diócesis se hallaban «vacantes» al producirse la muerte o el traslado de un obispo, y los cabildos metropolitanos, según los cánones, gobernaban de facto los obispados por medio de un Vicario General electo. Al estar ya constituidos cuando llegaba el arzobispo, bien por presentación real, ya por oposición, los prebendados, canónigos y demás dignidades se mostraban reacios a entregar el poder jurisdiccional, porque ello suponía ceder el control de los diezmos al nuevo prelado. No olvidemos que los eclesiásticos acostumbraban a vender las rentas de los diezmos a los arrendadores por un precio fijo que determinaban a voluntad. En 1584, Toribio puso la gruesa de los diezmos en 32.000 pesos ensayados y se remató en Gonzalo de Molina. Según el Padre Baltasar Ramírez, «solían valer no más de 25.000 pesos y han recibido este aumento por las viñas que se han plantado, de que se coge gran suma de arrobas de vino, y se han hecho muchas labores de trigo y maíz» ${ }^{12}$. Algunas veces los rematadores se quejaban de haber pagado un precio superior al real por el contrato de compraventa o arrendamiento de los diezmos y denunciaban a los prebendados ${ }^{13}$.

${ }^{10}$ García Irigoyen (1906), tomo II, p. 243; Vargas Ugarte (1959), tomo II, p. 180; E. Dussel (1983), p. 456. Sin embargo, en una carta a Felipe II, con fecha en el Callao, 16 de abril de 1598, el Virrey Luis de Velasco le comunicaba que la renta de la catedral ascendía hasta 60.000 pesos ensayados. Véase R. Levillier (1926) (en adelante, GP), tomo XIV, p. 95.

${ }^{11}$ Vargas Ugarte (1959), tomo I, pp. 145; Dussel (1983), p. 530.

12 B. Ramírez (1906) [1597], p. 312.

${ }^{13}$ Según Paulina Numhauser Bar-Magen (2005, pp. 197-209), los diezmos de la coca de 1565 fueron rematados en el Obispado del Cuzco por 24.444,44 pesos ensayados, cuando en realidad los diezmos no valían más de 16.000 pesos de plata corriente. 
Cuando Toribio llegó a Lima en 1581 convocó de inmediato el Tercer Concilio Limense -15 de agosto de 1582 a 18 de octubre de 1583-, dejando clara su intención de ejercer como el máximo representante de la Iglesia en el Perú. Había que reformar el clero y promover la iglesia diocesana frente al monopolio ejercido por las órdenes mendicantes en las parroquias o doctrinas de indios. Como es sabido, las propiedades dedicadas a la producción agrícola en manos del clero regular estaban exentas del pago del diezmo. En tal sentido, las desavenencias entre el Arzobispo y el Virrey García Hurtado de Mendoza y los jesuitas son bastante conocidas. Toribio se opuso a que los indios de la doctrina de San Lázaro se incorporasen a la parroquia de Santiago del Cercado. No quería perder el curato, así que, más que una reacción contra el derecho de la Corona de Castilla a ejercer el Patronato regio sobre la iglesia, su actividad política fue un intento claro de acabar con el monopolio de las órdenes religiosas ${ }^{14}$. Su voluntad era convertir los asentamientos de San Lázaro y el Cercado en parroquias bajo el control de los seculares, elevando así las rentas episcopales a través del cobro del diezmo ${ }^{15}$. Pero la negativa de las órdenes religiosas, en especial la de la Compañía de Jesús, a abandonar su independencia en la acción pastoral y a colaborar en el fortalecimiento de los obispados dio al traste con los objetivos del prelado ${ }^{16}$.

Mucho menos conocidos son los numerosos pleitos habidos entre el Arzobispo y sus acólitos, por un lado, y el cuerpo presbiterial, por otro. Toribio no podía elegir a los miembros de su Cabildo, ya que los canónigos y demás dignidades lo eran por presentación real o por oposición, aunque el Obispo podía elevar candidatos o comunicar al monarca sobre los clérigos beneméritos de su diócesis que se hacían merecedores de alguna prebenda. Esto hacía que aquellos miembros del Cabildo que habían sido elegidos y nombrados en España protestaran, consolidándose como un cuerpo defensor de la posición regalista del monarca frente al Arzobispo. Los únicos cargos que éste podía designar eran los de provisor, secretario de cámara y capellán, independientes de la jurisdicción del Cabildo y personas de su máxima confianza. Ello dio lugar a duros enfrentamientos y negociaciones, conflictos e incidentes que alteraron la vida interna de la Catedral limeña ${ }^{17}$.

Uno de estos conflictos perturbadores afloró como consecuencia de la negativa de los prebendados a contribuir con el 3 por ciento para el sustento del Seminario ${ }^{18}$. En 1591 Toribio compró unas casas que distaban muy poco de la Catedral y del

\footnotetext{
${ }^{14}$ Sin ir más lejos, el 23 de diciembre de 1593 Felipe ir hizo una consulta al Virrey García Hurtado de Mendoza sobre la conveniencia de que los frailes volvieran a sus monasterios, dejando las doctrinas de indios en poder de los seculares. Vid. Emilio Lissón Chaves (1945), tomo IV, pp. 166.

${ }^{15}$ Vicente Rodríguez Valencia (1957), tomo II, pp. 28-34.

${ }^{16}$ Alexandre Coello de la Rosa (inédito).

${ }_{17}$ Antonio Ybot León (1962), pp. 234-235.

${ }_{18}$ Carta del Cabildo eclesiástico a Felipe II, Lima, 30 de abril de 1591, en E. Lissón Chaves (1944-45), tomo III, pp. 543-546. Véase también R. Vargas Ugarte (1959), tomo II, p. 86.
} 
palacio que le servía de morada. Admitió en ella unos 28 jóvenes y los puso bajo la dirección del bachiller Hernando de Guzmán, quien fue nombrado rector ${ }^{19}$. Sin embargo, su fundación había sido precipitada, y desde el principio contó con la oposición del Virrey Don García Hurtado de Mendoza, quien por aquel entonces había iniciado la construcción del Palacio Virreinal, con la del Cabildo catedralicio y de los regulares, a quienes se exigía el pago del 3 por cien de sus rentas para contribuir a la compra de las casas y a su sostenimiento ${ }^{20}$. Nombró administrador especial de dichos fondos a Don Pedro de Escobar, mayordomo de la catedral y cura de la parroquia de Santa Ana de Lima. Los prebendados de la catedral se consideraron exentos y llevaron al Arzobispo a los tribunales. Y perdieron ${ }^{21}$. En su defensa argumentaban que las prebendas que recibían eran patronadas y que el Arzobispo no podía exigir ninguna «pensión» sin permiso del monarca. Desde el inicio de su gobierno eclesiástico, Toribio estableció una comunicación directa con la Santa Sede en materia eclesiástica, sin pasar por el Consejo de Indias. Pero, como señala Vicente Rodríguez Valencia, su intención no era la de atentar contra el Patronato regio ${ }^{22}$, tal y como sostenían en su contra los prebendados del Cabildo catedralicio. Pretendía resolver sus interrogantes o dudas sobre materias pastorales con la mayor eficacia posible. Y una de ellas hacía referencia a la disciplina capitular y al celo con que dichos prebendados defendían sus privilegios frente a cualquier intromisión externa ${ }^{23}$. Las disputas tuvieron su origen, como es sabido, en los capítulos 28 -«Que los diezmos de las doctrinas de yndios se arrienden por sí»- y 29 - «Que los diezmos de las villas y lugares y otras partes de españoles se arrienden de por sí»- del sínodo diocesano celebrado en 1586 en Santiago Yambrasbamba, provincia de Pacallas. Toribio transfirió el arrendamiento íntegro — in solidum — de los diezmos directamente a los municipios, causando un gran perjuicio a los miembros del Cabildo, que hasta aquel momento venían ejerciendo esta función ${ }^{24}$. En su defensa, denunciaban que los sínodos eran convocados allí donde el Arzobispo estuviere llevando a cabo su Visita, sin la previa presentación ante el monarca y el Consejo de Indias ${ }^{25}$. El

${ }^{19}$ R. Vargas Ugarte, SJ, Tomo II, 1959, pp. 193. En 1595, Guzmán fue nombrado canónigo del Cabildo de la catedral. En 1602 el Seminario abrió de nuevo sus puertas, pero Guzmán renunció al cargo de rector (V. Rodríguez Valencia, Tomo II, 1957, pp. 178).

${ }^{20}$ Memorial del arzobispo Mogrovejo sobre el pago del 3 por ciento para el Seminario, en AGI, Patronato 248, R ${ }^{\circ}$ 23, en: E. Lissón Chaves, Tomo IV, 1945, pp. 15-16; 19. Véase también V. Rodríguez Valencia, 1957, pp. 393 y ss.

${ }^{21}$ V. Rodríguez Valencia (1948), pp. 169. Los prebendados gozaron siempre de privilegios exclusivos que los salvaguardaban de la autoridad episcopal. Un ejemplo lo constituyen los procesos de jueces adjuntos (Archivo Capitular de Lima, Sección «Libros Importantes». Proceso de Jueces Adjuntos, 1603-1719).

${ }^{22}$ V. Rodríguez Valencia (1948b).

${ }^{23}$ V. Rodríguez Valencia (1957), pp. 163-176.

${ }^{24}$ M. Patricia Martini (1991), pp. 464-465.

${ }^{25}$ Según M. M. McGlone (199, p. 228) «Toribio’s choice to hold synods in outlying areas served a double purpose. By so doing he demonstrated that he considered the rural missions to be integral components of the Archdiocese and he encouraged the «city priests» to broaden their horizons». 
Cabildo tampoco era invitado expresamente, con lo cual se cometía un defecto de forma, lo que equivalía a decir que el sínodo no se había convocado legítimamente ${ }^{26}$.

Toribio siempre quiso intervenir en las causas civiles y criminales de los canónigos para limitar al máximo sus posibilidades de acción. El nombramiento de su cuñado y primo, Don Francisco de Quiñones y Villapadierna, como mayordomo reiteraba la voluntad del Arzobispo de entregar la administración de las rentas episcopales a un familiar de su entera confianza ${ }^{27}$. Al fiscalizar el comportamiento de los prebendados pretendía evitar todo tipo de corrupción o simonía imponiéndoles penas pecuniarias o la excomunión latae sententiae. Pero éstos reaccionaron y el 30 de marzo de 1587 presentaron una querella contra el Arzobispo por no cumplir los autos y provisiones de la Real Audiencia ${ }^{28}$. Tres años después, el 30 de abril de 1590, el Cabildo eclesiástico escribió una extensa carta a Felipe is en que acusaban a Toribio de «alterar la posesión que tenemos de administrar y repartir los diezmos». También se quejaban de que el Seminario había permanecido cerrado desde 1583 hasta 1590, pero Toribio continuaba cobrando «gran cantidad de pesos para el dicho seminario así de tres por ciento de las rentas de los beneficios como de mucha cantidad de penas que aplicó en la visita para el dicho seminario ${ }^{29}$. Al destacar su avidez recaudadora, los miembros del Cabildo se erigían en los defensores del Patronato Regio y cuestionaban la lealtad de Toribio. El objetivo no era otro que suspender la legislación conciliar hasta que el caso se resolviera en España.

Toribio había descubierto irregularidades en la administración y repartición de las rentas eclesiásticas por parte del Cabildo. Le preocupaba especialmente la parte del diezmo -el noveno y medio- que correspondía a los hospitales de españoles e indios y que no percibían. Pero los privilegios especiales de algunas diócesis, como la de Lima, impedían que los prelados pudieran juzgar a sus dignidades. El Concilio de Trento (sesión 25, capítulo 6) había dispuesto la elección anual de dos prebendados, quienes estarían encargados, junto con el obispo, de juzgar todas las causas referentes a las dignidades y beneficiarios ${ }^{30}$. Monseñor Carlos García Irigoyen apuntaba que la primera elección de «jueces adjuntos» se efectuó

${ }^{26}$ M. Patricia Martín (1991), pp. 464-466.

${ }^{27}$ A. de León Pinelo (1653), pp. 189-190. No obstante, Toribio nombró una comisión, encabezada por el arcediano doctor Pedro Muñiz, los dominicos fray Feliciano de Silva y fray Tomás de Morales, y el jesuita Esteban de Ávila, que se reunió el 18 de diciembre de 1594 para establecer un control del dinero administrado por su mayordomo Quiñónez. Vid. Lohmann Villena (1992).

28 «Testimonio de autos seguidos en dicha Audiencia a instancia del deán y cabildo de Lima sobre las constituciones sinodales hechas y mandadas publicar y observar por el arzobispo don Toribio Mogrovejo acerca de los diezmos de su arzobispado». A. de Lima. Leg. 310. 15861587, en E. Lissón Chaves (1944-45), tomo III, pp. 469-480.

${ }^{29}$ E. Lissón Chaves (1944-45), tomo III, pp. 543 y 547-548.

${ }^{30}$ R. Vargas Ugarte (1959) tomo II, p. 171. 
en 1583, poco después del Tercer Concilio Limense, y los canónigos Cristóbal de León $^{31}$ y Juan de Balboa fueron elegidos por votación. Esto fue un motivo de serios conflictos entre Toribio de Mogrovejo y el entonces procurador de la iglesia de Quito en el Concilio de Lima, Don Pedro Muñiz Arias ${ }^{32}$, pues el primero consideraba que todos los clérigos estaban sujetos en primera instancia a sus prelados, y al someter su autoridad a la supervisión de dichos jueces, su poder quedaba menoscabado. Por el contrario, para los canónigos representaba gozar de un privilegio exclusivo que los salvaguardaba frente a la autoridad episcopal ${ }^{33}$. Queda claro, pues, que el Cabildo no actuó en ningún momento como una institución de apoyo a la labor evangélica del Arzobispo. Muy al contrario, sus miembros cerraron filas contra lo que consideraban una violación de sus privilegios económicos y denunciaron al Arzobispo por considerar que se entrometía en el fuero interno del Cabildo.

Efectivamente, los canónigos fueron acumulando muchas propiedades e ingresos provenientes de herencias, donaciones, capellanías y buenas memorias fundadas en la catedral u otras que obtenían de los patronos de las mismas ${ }^{34}$. A menudo se ausentaban de sus obligaciones para realizar visitas eclesiásticas y extorsionar a sus feligreses, obligándolos a trabajar en las minas, explotaciones agrícolas y ganaderas. Lo peor de ello era que utilizaban la mano de obra de aquellos indios a quienes supuestamente evangelizaban, lo que obligaba al prelado a supervisar las irregularidades en el cumplimiento de sus obligaciones ${ }^{35}$. El capítu-

${ }^{31}$ En 1599, el Virrey Velasco describía al canónigo Cristóbal de León como un «hombre ejemplar pio y limosnero dado a cosas espirituales» y lo recomendaba para una dignidad en el Cabildo eclesiástico. Véase R. Levillier (1926), tomo XIV, p. 236.

${ }^{32}$ El Padre Muñiz de Carvajal (Baeza, 1545-Lima, 1616) llegó a la Ciudad de los Reyes en 1568 acompañado de su familia. En 1575 participó en una Junta consultiva convocada por el Virrey Francisco de Toledo en la que se trataba de justificar la utilización del trabajo de los indios para la industria minera en atención al bien común -G. Lohmann Villena (1949, pp. 9596)-. En 1581 asistió al Tercer Concilio Limense como arcediano del Cuzco. Dos años más tarde fue nombrado procurador de la iglesia de Quito, pero su intención no era otra que volver a la capital. Y así fue. En 1587 el Conde de Villar lo nombró visitador y protector de la Universidad de San Marcos, en la cual se había doctorado a principios de la década de 1570. En 1593 fue nombrado Deán y vicario general de la catedral de Lima. Su salud era precaria, pero ello no le impidió hacer una gran fortuna. Entre 1598-1599 ejerció como rector de la Universidad de San Marcos, cargo que volvió a desempeñar entre 1614-1615. Tuvo otros cargos y menciones especiales, como las de calificador del Santo Oficio y catedrático de prima en la Universidad, que justifican el calificativo del Arzobispo Toribio de hombre «muy docto». Véanse Manuel de Mendiburu (1885, t. V, pp. 387-88) y K. V. Fox (1962, pp. 73-74).

33 C. García Irigoyen (1906), tomo II, p. 26. Para más información, véase Archivo del Cabildo de Lima, Sección Libros Importantes. Proceso de Jueces Adjuntos, 1603-1719.

${ }^{34}$ R. Vargas Ugarte (1959), tomo II, pp. 180-181.

${ }^{35}$ V. Rodríguez Valencia (1957), p. 82. La figura de Francisco de Ávila, cura de la parroquia de indios de San Damián en Huarochirí y canónigo del Cabildo de la Catedral de Lima es, al respecto, significativa. 
lo 93 del Sínodo de 1585, celebrado en Santo Domingo de Yungay, provincia de Huayllas, establecía la obligatoriedad del Cabildo de asistir en pleno a la llamada del prelado. A pesar de que las asambleas sinodales eran convocadas con suficiente antelación, los prebendados no estaban de acuerdo en que se celebraran sin su conocimiento. Pero lo que contradecía su asistencia era que se celebraran tan lejos de la capital. Las visitas pastorales eran, para Toribio, parte integral de su misión episcopal, lo que exigía que los sínodos se celebraran «sobre el terreno» ${ }^{36}$. Por el contrario, el clero capitalino pretendía celebrarlos en la capital. Con este fin escribieron un Memorial, con fecha en Lima, 7 de abril de 1587, en el que se quejaban de los inconvenientes de celebrar dichos sínodos en la sierra y pedían que las actas sinodales no se publicaran hasta que fueran vistas por el Consejo de Indias ${ }^{37}$. Tras la respuesta favorable de Felipe in al Cabildo a través de la Real Cédula, con fecha en Madrid, de 16 de enero de 1590, es más que probable que la mayoría de ellos no lo acompañara en sus largos desplazamientos apostó$\operatorname{licos}^{38}$.

Llegados a este punto podemos deducir que las relaciones de Toribio con sus prebendados fueron muy conflictivas. La visita efectuada en 1598 por el doctor Miguel de Salinas, Provisor y Vicario General del arzobispado de Lima -se refiere al examen de documentación de la curia-, dio lugar a una serie de pleitos contra los prebendados del Cabildo. El Arzobispo acusó a algunos de ellos de no haber dicho los maitines después de la oración y no estar sentados en las sillas del coro, sino abajo, y de hacer notorias ausencias de sus deberes catedralicios ${ }^{39}$. Al chantre, Don Esteban Fernández Vosmediano, le acusó de no enseñar el canto a los clérigos del coro. Igualmente le acusó, juntamente con el tesorero, Don Cristóbal Medel, y el canónigo Don Antonio de Molina ${ }^{40}$, de haber entregado una campana de la catedral para la artillería y de no haberla cobrado. El maestrescuela, Don Mateo González de Paz, fue acusado de no leer ninguna lección en la Iglesia. También sostuvo un pleito contra uno de sus secretarios, el canónigo Don

${ }^{36}$ McGlone (1991), pp. 227-228.

37 Vargas Ugarte (1959), tomo II, pp. 89-90.

${ }^{38}$ Los Sínodos de 1590 y 1592 se celebraron en Lima. Vargas Ugarte (1959), tomo II, p. 89; M. Patricia Martini (1991), p. 468.

${ }^{39}$ Las ausencias que podían hacerse lícitamente del coro, culto divino y administración de los Santos Sacramentos estaban reglamentadas por el llamado recle. Dicho recle estaba establecido en cuatro meses desde la erección de la catedral, efectuada por el arzobispo Jerónimo de Loayza. Luego, la sesión XXII del tercer período del Concilio de Trento (1562-1563) lo dejó establecido en tres. Finalmente, Toribio de Mogrovejo y el III Concilio Limense lo rebajaron a un mes, siendo motivo de un largo litigio entre los capitulares y el Arzobispo. Véase C. García Irigoyen (1906), tomo II, 1906, p. 203.

40 Don Antonio de Molina y el jesuita José de Acosta fueron teólogos consultores del arzobispo en el Tercer Concilio Límense. Vid. Rodríguez Valencia (1957), p. 95. 
Bartolomé Menacho, sobre una capellanía ${ }^{41}$. Todo ellos fueron condenados a pagar una sanción pecuniaria, siendo exhortados a no reincidir en los $\operatorname{cargos}^{42}$.

El 26 de abril de 1584, Toribio escribió una carta a Felipe II en que recomendaba que no se dieran capellanías a todos aquellos prebendados que ya disfrutaban de canonjías, dignidades u otros beneficios ${ }^{43}$. Su intención no era otra que romper la tupida red de los afines que se había tejido alrededor de los capitulares, lo cual favorecía indirectamente a otros sacerdotes como el Padre Alonso de Huerta. Antes de pronunciarse, el monarca escribió una Real Cédula al Arzobispo de fecha 8 de marzo de 1588 en la que solicitaba una relación de dichas capellanías, así como de la cantidad que pagaban ${ }^{44}$. Toribio cumplió y el 22 de enero de 1593 prohibía explícitamente que se dieran capellanías a los miembros del Cabildo.

En 1601, Don Joan de Solórzano Castillo y Don Diego Hernández de Medina, colegiales del Seminario, acusaron al canónigo Don Juan Díaz y al racionero Don Pedro Mauricio de Mendoza, prebendados del Cabildo, de malos tratos, «llamándonos bellacos desvergonzados y dándonos de empellones y diciéndonos que si no les servimos de rodillas no [h]emos de ir a la iglesia y diciendo que este no es colegio, sino cueva de ladrones». El problema tenía que ver con la intención del Arzobispo de otorgar las seis capellanías de erección de la catedral que todavía permanecían vacantes a los colegiales del Seminario. Sugirió que a título de ellas se podrían ordenar dichos colegiales y que fuesen beneficios perpetuos a cargo de las rentas del Cabildo metropolitano ${ }^{45}$. Al tratarse del Seminario, el Arzobispo no dudó en intervenir rápidamente contra aquellos provocadores que se erigían en los defensores del Patronato regio. El 16 de enero de 1602, los jueces adjuntos, Don Mateo González de Paz, maestrescuela, y el canónigo Don Bartolomé Menacho, lo imputaron por fulminar dos procesos criminales contra dichos prebendados sin tener jurisdicción para ello. Sin negar las acusaciones, los jueces acusaron al prelado de un defecto de forma por haber mandado apresar al racionero sin estar ellos presentes. En pocas palabras, censuraban su proceder, de lo cual resultaba que «los delitos y culpas del dicho Don Pedro se han quedado impunitos y sin castigo» ${ }^{46}$.

\footnotetext{
${ }^{41}$ El canónigo Bartolomé Menacho fue secretario del Tercer Concilio Limense (1582) y secretario de cámara del arzobispado. En una carta de recomendación escrita a Felipe II, con fecha en Lima, 27 de mayo de 1591, el arzobispo Mogrovejo lo consideraba una «persona virtuosa y muy recogido que merece mucho». E. Lissón Chaves (1944-45), tomo III, p. 626. Fue elegido juez sinodal en 1613 y falleció en 1640. Véanse Rodríguez Valencia (1957), tomo II, p. 95, y J. Dammert (1996), p. 309.

${ }^{42}$ C. García Irigoyen (1906), tomo II, pp. 214-217.

${ }^{43}$ Según el capítulo 22 del Patronato Real se establecía que «nadie tenga dos beneficios y prebendas ni oficios en una ni diversas iglesias». E. Lissón Chaves (1945-46), tomo IV, pp. 64-65.

${ }^{44}$ E. Lissón Chaves (1944-45), tomo III, pp. 346-347.

${ }^{45}$ E. Lissón Chaves (1945-46), tomo IV, pp. 522-523.

${ }^{46}$ Archivo del Cabildo Eclesiástico, Sección Libros Importantes. Proceso de Jueces Adjuntos, 1603-1719.
} 


\section{LOS PLEITOS ENTRE EL PÁRROCO ALONSO DE HUERTA Y EL CABILDO ECLESIÁSTICO}

En la segunda parte de este ensayo vamos a analizar las causas que algunos prebendados lanzaron contra un fiel colaborador del arzobispo Mogrovejo. Se trata del conocido párroco y quechuista Alonso de Huerta. No es mucho lo que se conoce de su vida. Sabemos que nació en la localidad de San León de Huánuco y que era hijo de Alonso de Huerta y Ana de Cerezo. Su padre fue un antiguo soldado residente en esa ciudad. En 1554, salió con Don Miguel de la Serna para participar en la batalla de Pucará contra las fuerzas de un antiguo poblador de Popayán, el carismático extremeño Francisco Hernández Girón (1552-1554) ${ }^{47}$. Era un buen estudiante, graduado como maestro en artes y doctorado en teología en la Universidad de San Marcos de Lima. Recibió la tonsura clerical en 1585, previa presentación y colación el 10 de junio de 1584 de la constancia respectiva expedida por la curia arzobispal ${ }^{48}$. El 26 de abril de 1584, Toribio escribió una carta a Felipe II en la que solicitaba permiso para nombrar algunos ministros como acólitos y capellanes «sin esperar que se cumpla todo el número de dignidades canonjías raciones y medias raciones y los otros oficios que dice la erección de esa iglesia» ${ }^{49}$. No hay duda de que uno de ellos fue el Padre Alonso de Huerta. Efectivamente, el 28 de noviembre de 1590 el Arzobispo lo nombró vicario del Cercado para administrar los sacramentos a los indios de la doctrina de San Lázaro que habían sido trasladados a la parroquia ${ }^{50}$. Con este objetivo, se dispuso a edificar una iglesia a su cargo, y según el testimonio que prestó sobre la vida y virtudes del prelado, con fecha en Lima, 10 de noviembre de 1631, los padres de la Compañía de Jesús manifestaron abiertamente sus reparos y trataron por todos los medios de impedir su edificación ${ }^{51}$. Poco después, el 28 de diciembre de 1591, tuvo lugar el famoso milagro de la famosa Virgen de Copacabana que sacudió a la parroquia de indios del Cercado. Los hechos son bien conocidos. En el día festivo de los Santos Inocentes, la improvisada iglesia que Toribio mandó construir en el Cercado fue deliberadamente descubierta por la parte superior del altar mayor.

\footnotetext{
47 Sobre la rebelión que protagonizaron Hernández Girón y su clientela de «soldados vagabundos» contra la autoridad de la Audiencia de Lima (1552-1554), véase las Noticias de la rebelión de Fco. Hernández Girón. Colección de Jesuitas, Ms. 250-254, CLXXXVIII, Real Academia de la Historia, Madrid.

${ }^{48}$ Los obispos tenían la obligación de dar colación y canonical presentación al candidato. A partir de entonces, éste entraba en posesión de la prebenda y gozaba de sus frutos. Vid. C. García Irigoyen (1906), tomo I, pp. 257-278, R. Vargas Ugarte (1959), tomo II, pp. 178, y J. Dammert (1996), pp. 305-306.

${ }^{49}$ E. Lissón Chaves (1944-45), tomo III, pp. 346-347.

${ }^{50}$ C. García Irigoyen (1906), tomo II, pp. 185-188.

51 Archivo Arzobispal de Lima (AAL), Causa de la Beatificación del arzobispo Toribio Alfonso de Mogrovejo, folios 323-326. Cfr. García Irigoyen (1906), tomo II, p. 181.
} 
Indignado, el arzobispo abrió una investigación para descubrir a los responsables del vandálico acto, al tiempo que ordenó al párroco Don Juan de Pineda y a sus feligreses que organizaran una solemne procesión con el objetivo de trasladar la imagen a la catedral. Pero, alrededor de las diez o las once de la mañana, justo antes de dirigirse hacia la ciudad, la Virgen de Copacabana y el niño Jesús empezaron a sudar copiosamente ${ }^{52}$. El milagroso acontecimiento fue observado por un grupo de mujeres mientras el Padre Juan de Pineda celebraba la misa matinal del sábado en sustitución del Padre Huerta. De inmediato, una histeria colectiva se extendió entre los asistentes, quienes

«encomençaron a dar muy grandes voces y a llorar e ymportunado este testigo dellas y por que con la devocion que tenian no se subiesen al altar se subio sobre el dicho altar y con algodones e cintas que las dichas mugeres cortaban de los mantos y con las lechuguillas de las camisas que se quitaban a pedaços y con los rosarios este testigo limpio el rostro de la dicha ymagen y del niño que tenia en los braços muchas vezes por que estuvo sobre el dicho altar muy gran rato y de puro cansado de llegar al rostro de nuestra Señora y del niño Jesús.» ${ }^{53}$

Inmediatamente, españoles e indios de todos los rincones de Lima se agolparon frente a las puertas de la iglesia con el fin de venerar a la Mater Dolorosa y a su hijo ${ }^{54}$. Para Carlos García Irigoyen, basándose en el primer informe de Antonio de León Pinelo, las consecuencias del milagroso acontecimiento fueron todavía más milagrosas ${ }^{55}$. Así, «los efectos del sudor sagrado fueron milagrosos, porque al contacto de sus gotas, los ciegos lograron vista, pies los tullidos, los mancos brazos, y todos los que se humedecieron con aquella lluvia verdaderamente celestial, quedaron libres de varias enfermedades y dolencias» ${ }^{56}$.

Poco después, Toribio decidió fundar una cofradía en honor de la Virgen de Copacabana, sin licencia del Cabildo. El 25 de junio de 1594, designó a Don Alonso de Huerta como capellán y mayordomo de la capilla de Nuestra Señora de Copacabana, situada en el cementerio de la Catedral ${ }^{57}$. Desde 1592 ocupó por oposición la Cátedra de Lengua Quechua en la Universidad, convirtiéndose en

\footnotetext{
${ }^{52}$ «Testimonio de la información recibida por orden del Arzobispo de los Reyes, D. Toribio de Mogrovejo, referente al milagro obrado por Nuestra Sra. de Copacabana» (1591-1592). Cabeza de la información, en Patronato 248, R. 24, en E. Lissón Chaves (1945-46), tomo IV, p. 5 .

${ }^{53}$ Ibidem, pp. 5-7.

${ }^{54}$ Domingo Angulo (1971), pp. 73-77. OP, «Nuestra Señora de Copacabana», Revista Histórica (Lima-Perú), Tomo 5, Entrega III, 1917b, pp. 323-325; R. Vargas Ugarte (1971), pp. 73-77.

${ }^{55}$ A. de León Pinelo (1653), pp. 117-118.

${ }^{56}$ C. García Irigoyen (1906), tomo I, p. 31.
} 
uno de los mejores especialistas de la capital ${ }^{58}$. En una carta que escribió al Rey, con fecha en Lima, 29 de abril de 1599, decía que hacía más de nueve años que predicaba y adoctrinaba a los indios en su lengua «en esta santa Iglesia los domingos y fiestas», actuando también como su abogado defensor de los malos tratamientos que recibían de los españoles. El 22 de abril de 1599, el arzobispo Toribio escribió varias cartas de recomendación al Consejo de Indias en las que elogiaba la labor del Padre Huerta, doctor y decano de las facultades de Teología y Artes de la Universidad de San Marcos y predicador incansable, de cuarenta años de edad, con un conocimiento extraordinario de la lengua de los naturales, y en extremo aficionado a los indios «y [que] les favorece y enseña el catecismo en la puerta de la Iglesia» ${ }^{59}$.

Pocos años antes, el 14 de abril de 1595, Toribio escribió una carta a Felipe II en la que le recordaba que los indios que el Marqués de Cañete redujo y pobló en la parroquia del Cercado no habían vuelto al barrio de San Lázaro, según lo dispuesto en el decreto ejecutorial de 1591, y solicitaba que volvieran al antiguo barrio de pescadores bajo el cuidado espiritual del párroco de la catedral, Don Alonso de Huerta, a quien Toribio había nombrado en 1590 vicario del Cercado. En un tono mucho más moderado y conciliador, el Arzobispo elogiaba la labor misionera de los padres Juan Pérez de Aguilar y Alonso de Villalobos en la parroquia, siguiendo los consejos del Papa Gregorio XIV (1535-91), pero apelaba a la mayor comodidad y cercanía del asentamiento original ${ }^{60}$. A pesar de sus intentos, el Virrey Don Luís de Velasco se opuso con firmeza a la voluntad del Arzobispo. En dos cartas escritas en Lima, de fechas 13 de abril y 3 de noviembre de 1598, Velasco advertía al monarca de los peligros de trasladar a los indios del Cercado de vuelta a San Lázaro. A su juicio, se trataba de una

«tierra estéril y pedragosa, expuesta a las avenidas del río y a los daños y robos de todas gentes sin que pueda haver defensa, y ansí convendría

${ }^{57}$ Antonio de Egaña, tomo V, p. 37; García Irigoyen (1906), tomo II, pp. 179-181; Rodríguez Valencia (1957), tomo II, p. 315.

${ }^{58}$ Esta cátedra fue fundada en 1560 en la Universidad de San Marcos de Lima, por Real Cédula del 19 de septiembre de 1560, en AGI, Indiferente General, 427, Libro 30, folios 316318. Este honor le había correspondido anteriormente al canónigo Don Juan de Balboa, fallecido en mayo de 1591. Fue el primer doctor criollo del Perú especializado en asuntos indígenas y catedrático de quechua de la Universidad Mayor de San Marcos. Véase Rodríguez Valencia (1957), tomo II, pp. 287-288, y J. Dammert (1996), pp. 304-305

${ }^{59}$ Lissón Chaves (1945-46), tomo IV, pp. 275-276. Véase también J. Dammert (1996), pp. 305-306, y Rodríguez Valencia (1957), tomo II, pp. 293-294.

${ }^{60}$ García Irigoyen (1906), tomo I, pp. 95-100. El Padre Juan Pérez de Aguilar fue uno de los testigos que declararon haber presenciado el milagro. Vid. «Testimonio de la información recibida por orden del Arzobispo de los Reyes, D. Toribio de Mogrovejo, referente al milagro obrado por Nuestra Sra. de Copacabana» (1591-1592). Declaraciones de los testigos, en Patronato 248, R. 24, Cfr. Lissón Chaves (1945-46), tomo IV, p. 7. 
que no sólo estos indios vivan en el Cercado, pero que otros, que por algunas partes de la ciudad están derramados, se reduxesen a él, no siendo algunos oficiales que tienen tiendas, porque en ninguna otra parte de la ciudad ay sitio acomodado.» ${ }^{61}$

El argumento del Virrey era cristalino. No sólo ensalzaba la labor evangelizadora de la Compañía de Jesús, sino que presentaba el asentamiento de San Lázaro como la antítesis del Cercado. Un asiento expuesto a las fuerzas incontroladas de la naturaleza, hostil y agreste, donde los indios eran continuamente agraviados por los numerosos españoles pobres, mestizos, negros, mulatos y vagabundos que vivían entre ellos ${ }^{62}$. Para evitar tales molestias, el Virrey describía la parroquia del Cercado como un lugar civilizado, «muy bueno y cercano» a la ciudad, donde los indios vivían en orden y policía bajo el cuidado y vigilancia permanente de la orden ignaciana. Por todo ello, recomendaba que todos los indios que vivían diseminados en la capital fueran reducidos a la parroquia del Cercado ${ }^{63}$.

Pero al mismo tiempo que alababa las virtudes de los religiosos de la Compañía, Velasco escribió una carta al Rey, con fecha en Lima, 15 de mayo de 1599, en la que acusaba directamente al maestro Alonso de Huerta de inquietar a los indios del Cercado para que iniciaran acciones legales en el Real Consejo a fin de «sacarlos de allí» ${ }^{64}$. En una carta escrita al Rey, con fecha en Lima, 29 de abril de 1599, el mismo Huerta reconocía que hacía más de nueve años que predicaba y doctrinaba a los indios en su lengua «en esta santa Iglesia los domingos y fiestas y a quien acuden en las quejas de los malos tratamientos que les hacen» ${ }^{65}$. Fruto de dichas gestiones, Don Pedro Cacay, alguacil del Cercado, acompañado de más de veinte indios y sus mujeres, decidió protestar airadamente por su situación de confinamiento en la parroquia. Para ello escribieron una carta a Felipe III en la que renovaban un poder notarial del año 1598 ante el escribano Don Rodrigo Gómez de Baeza, con fecha en Lima, 29 de abril de 1599, solicitando retornar al barrio de San Lázaro. Se quejaban de haber sido trasladados al Cercado contra su voluntad y exigían volver a sus casas y negocios en el antiguo barrio de los camaroneros, según lo dispuesto en la ejecutoria real de 1592. Ni el Virrey, ni los oidores de la Audiencia de Lima ni los jesuitas decían la verdad. Muy al contrario, los indios manifestaron su desacuerdo con el traslado y denunciaban que habían sido obli-

\footnotetext{
${ }^{61}$ Cartas del Virrey Luis de Velasco a Felipe II, en Egaña (1974), tomo VI (1596-1599), p. 527. Dichas cartas fueron publicadas originalmente por Levillier (1926), tomo XIV, pp. 83-88 у 122-123.

${ }^{62}$ Carta del Virrey García Hurtado de Mendoza a Felipe II, fechada en Lima, 17 de mayo de 1590, en Levillier (1926), tomo XII, pp. 164-165.

${ }^{63}$ Carta del Virrey Luis de Velasco a Felipe II, en Egaña (1974), tomo VI (1596-1599), pp. 526-528.

${ }^{64}$ Levillier (1926), tomo XIV, pp. 185-187.

${ }^{65}$ J. T. Medina Polo (1965), tomo I, p. 142.
} 
gados a residir en el Cercado por razones ajenas a su bienestar espiritual. Su autonomía había sido vulnerada y por ello se situaron en el bando del Arzobispo, reaccionando contra las políticas disciplinarias orientadas a preservar la mano de obra indígena, especialmente valiosa en la industria minera.

Fue precisamente Toribio quien nombró al Padre Huerta para ejercer la cura de almas en el Cercado y supervisar la doctrina de los indios de San Lázaro que se había creado en la parroquia ${ }^{66}$. Se trataba de afianzar la autoridad apostólica del episcopado frente a las órdenes religiosas, aliadas del monarca y del Consejo de Indias. En este orden de cosas, los obispos podían, al menos en teoría, recurrir al Cabildo eclesiástico para implantar su autoridad con respecto a las arbitrariedades del Virrey. Pero no fue así. Los prebendados actuaban como un cuerpo unificado e independiente, y en lugar de apoyar al prelado, defendían sus privilegios económicos frente a la intervención episcopal. Para muestra, un botón. El 2 de septiembre de 1594, el canónigo Cristóbal Sánchez de Renedo y el Deán y Vicario Provisor Pedro Muñiz Arias acusaron al Padre Huerta de administrar sacramentos a los indios y a los negros de San Lázaro sin tener el correspondiente título de cura $^{67}$. Asimismo, lo acusaron de no registrar los matrimonios ni las defunciones de los indios en los libros parroquiales, según lo establecido en la sesión del 11 de noviembre de 1563 del Concilio de Trento y en algunas asambleas sinodales (1585, capítulo 17). Dichos libros recogían los datos descriptivos y estadísticos sobre el número de feligreses, si eran indios o españoles, hombres o mujeres, el número de casas, familias, recursos, etc. Constituían la fuente directa utilizada para la elaboración del padrón de tributarios y la organización de los turnos de la mita minera. Al no poder determinar la edad de los indios por carecer de las partidas bautismales correspondientes, los canónigos querían llamar la atención sobre los notables perjuicios que el Padre Huerta estaba ocasionando al erario público ${ }^{68}$. Pero, más que la Hacienda Real, lo que les preocupaba realmente era la suya propia. Así, entre 1592 y 1595 le imputaron estar defraudando numerosos derechos parroquiales y atenciones de toda clase que les correspondían a ellos por bautismos, certificados, velaciones, entierros, misas cantadas, misas de réquiem, etc.

Los beneficios de los capitulares del Cabildo de Lima producían notables rentas, que permitieron a algunos de ellos fundar capellanías eclesiásticas o colativas, labrar capillas y altares e incluso «los sarcófagos en que serían sepultados» ${ }^{69}$. Se deduce que el control de almas, o conocimiento del número y estado de la feligre-

\footnotetext{
${ }^{66}$ García Irigoyen (1906), tomo I, pp. 179-181.

${ }^{67}$ Don Cristóbal Sánchez fue canónigo de la catedral del Cuzco y asistió a la fundación del Colegio Máximo de Lima de la Compañía de Jesús. Vid. R. Vargas Ugarte (1963), tomo II, p. 53.

${ }^{68}$ En el Sínodo de 1585, capítulo 17, se hizo hincapié en la importancia de llevar un registro lo más completo posible de los indios bautizados. Véase Martini (1988), pp. 342-347.

${ }^{69}$ Dammert (1996), pp. 313.
} 
sía era establecido por una institución que concebía a la población india como un recurso. Del número de indios dependían muchas de las posibilidades económicas del arzobispado. En una carta al Presidente del Consejo de Indias, con fecha en Lima, 25 de mayo de 1592, el Cabildo eclesiástico se quejaba de que las rentas decimales variaban y que los canónigos no podían sustentarse «honradamente» con tres mil pesos de plata ensayada de sueldo anual ${ }^{70}$. Desde el Tercer Concilio Limense, Toribio había prohibido a sus párrocos el cobro de derechos parroquiales a los indios por bautismos, casamientos, etc. ${ }^{71}$. El 29 de diciembre de 1590, el Virrey García Hurtado de Mendoza escribió una carta a Felipe in en la que denunciaba que los clérigos y prelados cobraban derechos a los indios por bautismos, casamientos y entierros, «lo qual antes de agora estaua prohibido a los curas de las doctrinas de los yndios, y esto los fatiga mucho por ser gente tan pobres y neçesitada ${ }^{72}$. Pero estas prácticas, así como las ofrendas, camaricos y derechos funerales ofrecidos por los fieles durante las misas y sepulturas, lejos de disminuir, aumentaron. Así, el 4 de marzo de 1593, los curas y sacristanes del Cabildo denunciaron al Padre Huerta por pretender enterrar a una india de San Lázaro en la capilla de Nuestra Señora de Copacabana, situada en la Catedral. Se trataba de un problema de jurisdicción, ya que la capilla y la difunta se hallaban dentro de los límites jurisdiccionales de la parroquia de San Lázaro. Y para los prebendados del Cabildo, San Lázaro era una de sus parroquias. Por todo ello, Cristóbal Sánchez de Renedo y Miguel de Salinas solicitaban al Arzobispo que

«[...] el dicho maestro huerta no entierre el cuerpo de la dicha difunta ni nos perturbe el uso de nuestro oficio y cuando de presente no [h]ubiere lugar de proveer lo que pedimos que sea Vuestra Merced que mande que sin atribuir derecho a ninguna de las partes de nosotros la enterremos y se depositen los derechos y prevenciones del dicho entierro y Vuestra Merced los mande adjudicar a quien mejor derecho tuviere sobre lo que pedimos justicia y costas y protestamos en el caso todo aquello que mas y mejor a nuestro derecho convenga.» ${ }^{73}$

El desprendimiento personal de los bienes terrenales fue una cualidad del Arzobispo Mogrovejo, pero no del clero diocesano. Ni tampoco del Deán Muñiz ni del resto de canónigos y prebendados del Cabildo catedralicio ${ }^{74}$. Sólo así se

\footnotetext{
${ }^{70}$ Audiencia de Lima, Leg. 310, en Lissón Chaves (1944-45), tomo III, pp. 674-75.

${ }^{71}$ Dicha prohibición fue reiterada en los decretos de los cinco sínodos celebrados entre 1594 y 1604. León Pinelo (1653), p. 102; Rodríguez Valencia (1957), tomo II, pp. 22 y ss; Martini (1991), p. 477.

${ }^{72}$ Lissón Chaves (1944-45), tomo III, pp. 556-565.

73 «Causas que siguen los curas de la Catedral contra el maestro Alonso de Huerta, capellán de Nuestra Señora de Copacabana (1592-1595)», «Papeles Importantes». Legajo $\mathrm{n}^{\circ}$ III. Expediente $n^{\circ}$ 4. Archivo Arzobispal de Lima (en adelante, AAL). AAL, folio 7.

${ }^{74}$ Sobre la fortuna acumulada por el Deán Muñiz, véase el trabajo de Fox (1962), pp. 74.
} 
explican sus recelos y desconfianzas y, como consecuencia, los cargos contra lo que consideraban una alteración de las «loables costumbres» del Virreinato. Lo cierto es que, al final, el Padre Huerta acabó enterrando a la difunta y llevándose los derechos por el funeral. Los canónigos montaron en cólera y denunciaron lo que para ellos era una auténtica provocación. Le acusaron de extorsionar a los indios en su propio beneficio y de causarles numerosos agravios. Sin embargo, parece que los más agraviados eran, sin duda, los canónigos. Para ellos el Padre Huerta era un extraño que ejercía como vicario sin la obligada presentación ante el Virrey. Pero lo cierto es que hizo las gestiones pertinentes en la Audiencia de Lima para obtenerla. El Doctor Castilla le aseguró que recibiría dicha presentación del Virrey, pero al final, como apunta Vicente Rodríguez Valencia, «todo se había concertado sin firmas». Dicha irregularidad en el nombramiento fue contemplada por los jesuitas del Cercado como un motivo de protesta. Si el título del Padre Huerta no estaba debidamente oficializado, entonces no tenía ningún derecho a administrar los sacramentos, y en consecuencia, debía irse. Toribio reaccionó y reclamó la doctrina del Cercado para el clero diocesano, ordenando al Padre Huerta inspeccionar los indultos apostólicos u otros privilegios pontificios que los jesuitas pudieran tener para administrar la comunión a los indios por viático, sin tener licencia del ordinario ${ }^{75}$. Como sabemos, los jesuitas no abandonaron la parroquia. Recurrieron al Virrey García Hurtado de Mendoza para defender sus derechos. En el otro lado se hallaban Toribio de Mogrovejo y el Padre Huerta, convertidos en adalides del clero diocesano frente a la Compañía de Jesús. Llegados a este punto, uno podría pensar que los curas del Cabildo eclesiástico hicieron causa común con el Arzobispo. Pero no fue así. A partir de 1592 denunciaron las actividades del Padre Huerta enarbolando los mismos argumentos que los jesuitas habían utilizado para expulsarlo del Cercado: la invalidez de su título de cura para administrar los sacramentos. Por todo ello, pensamos que el problema de fondo residía en el enfrentamiento entre una oligarquía eclesiástica local, centrada en el Cabildo, y un poder venido de fuera, representado en este caso por el Arzobispo y sus afines.

Historiadores como E. Dussel sostienen que el Cabildo fue el organismo de la toma de conciencia del clero criollo nativo. Su posición privilegiada le permitía actuar como mediador entre el poder civil y el religioso, entre el Virrey y la Audiencia, por un lado, y los obispos, por el otro ${ }^{76}$. De lo que no hay duda es que los prebendados limeños actuaban como un bloque con intereses comunes. Así, para contrarrestar las actuaciones del Padre Huerta no había otro remedio que deslegitimar su nombramiento. En primer lugar, los miembros del Cabildo consideraban que el Padre Huerta había sido designado temporalmente como Vicario del

\footnotetext{
${ }^{5}$ Rodríguez Valencia (1957), tomo II, p. 297.

${ }^{76}$ Dussel (1983), pp. 529-530.
} 
Cercado hasta que Felipe II otorgara la plena jurisdicción de la parroquia al arzobispado de Lima. Por tanto, en el caso de que la Compañía de Jesús, y no el Arzobispo, obtuviera dicha jurisdicción, las funciones del párroco debían quedar sin efecto. Y eso fue precisamente lo que denunciaron los curas del Cabildo ${ }^{77}$. El 10 de junio de 1591, tras la repentina muerte del Papa Gregorio xiv, un grupo de cardenales sentenció a favor de los jesuitas ${ }^{78}$. De manera casi simultánea, Felipe II y el Consejo de Indias promulgaron una ordenanza real, con fecha 12 de noviembre de 1591, en la que apoyaban la posición de la Compañía de Jesús y del Virrey, en contra de los intereses del Arzobispo Mogrovejo. La Compañía conservaría la parroquia del Cercado, fuera de la jurisdicción de la diócesis, hasta 1767, pero los indios originarios de San Lázaro debían volver a su antiguo barrio de pescadores ${ }^{79}$.

En segundo lugar, los miembros del Cabildo acusaban al Padre Huerta de usurpador, puesto que predicaba no sólo en la Catedral sino también en otras parroquias sin el correspondiente permiso, licencia o título del Patronato regio. En su defensa, el Padre Huerta declaraba que había sido presentado como vicario del Cercado ante el Virrey conforme al Real Patronato y que dicho título se refería no sólo a los indios del Cercado, sino a los que vivían en el barrio de San Lázaro. Curiosamente, en los cuatro años que llevaba ejerciendo, ninguno de los canónigos se había opuesto a su nombramiento. Los intentos de Toribio de controlar el Cercado fueron en vano. El 3 de mayo de 1592, el Virrey García Hurtado de Mendoza comunicó a Felipe in su intención de no permitir la edificación de otra iglesia en la parroquia ${ }^{80}$. A pesar de ello, el Padre Huerta no abandonó a sus feligreses. Muy al contrario, continuó ejerciendo como cura de indios y «predicándoles en lengua que ninguno de los dichos curas [de la catedral] la sabe para poder hacer usar y ejercer el dicho oficio» ${ }^{81}$. Al partir nuevamente a su segunda visita pastoral en julio de 1593, Toribio pidió encarecidamente al Padre Huerta que no los abandonara nunca. Exigía a su párroco que no renunciara a su misión evangélica a pesar de que ya no tenía ninguna jurisdicción sobre la parroquia. Pero los curas de la catedral querían impedir que administrara los sacramentos, acusándole de cobrar estipendios por ello ${ }^{82}$.

\footnotetext{
${ }^{77}$ AAL, «Papeles Importantes». Legajo $n^{\circ}$ III. Expediente $n^{\circ} 4$, folio 15.

${ }^{78}$ García Irigoyen (1906), tomo II, p. 182; J. Bromley y J. Barbagelata (1945), p. 59.

${ }^{79}$ Carta de Felipe is al Virrey García Hurtado de Mendoza, fechadas el 22 de junio y 12 de noviembre de 1591, en Egaña (1966), tomo IV, pp. 812-813 y 840-842.

${ }^{80}$ Audiencia de Lima, 32, en Lissón Chaves (1944-45), tomo III, p. 661.

${ }^{81}$ AAL, «Papeles Importantes». Legajo $n^{\circ}$ III. Expediente $n^{\circ} 4$, folio 17 . De acuerdo con lo dispuesto en el Tercer Concilio Limense, los Sínodos de Lima de 1586 y 1592 exigían al clero diocesano que aprendiera la lengua de los indios, so pena de perder el primer año la tercera parte de su salario, y así proporcionalmente hasta que demostraran haberla aprendido. Véase Martini (1988), pp. 359-365. No hay ninguna duda que el Padre Huerta defendía su posición enarbolando sus indiscutibles méritos como lingüista experto.

${ }^{82}$ El cobro de estipendios por la administración de los sacramentos a los indios traía como consecuencia que éstos se alejaran de la Iglesia para evitarse el desembolso. Martini (1988), pp. 332-336.
} 
Tras el milagro en la parroquia del Cercado, la construcción de una capilla en la catedral limeña y la posterior fundación en 1594 de la Cofradía de Nuestra Señora de Copacabana institucionalizó el culto de la Virgen Milagrosa ${ }^{83}$. Con ello se pretendía atraer no sólo a los fieles de dicha advocación, sino las limosnas de éstos -aceite y cera, pero también alhajas, ornamentos y objetos de culto-, con el aliciente de alojar en la iglesia a la Virgen. Dichos fieles pedían toda clase de servicios religiosos. Es de suponer que el volumen de misas y sufragios que en aquella capilla se encargaban y celebraban aumentó considerablemente, y, con ellos, también las ganancias. Uno de los privilegios de los cofrades consistía en poder recibir sepultura en la Capilla del Sagrario ${ }^{84}$. Pero algunos beneficiados de la Catedral reaccionaron al observar que la mayor parte del culto y las limosnas se estaban desplazando hacia dicha capilla. El 15 de abril de 1592, el Arzobispo Mogrovejo autorizó al Padre Huerta, como mayordomo de dicha Cofradía,

«para que pueda decir y diga las dichas misas así rezadas como cantadas de la dicha cofradía [de Copacabana] y las que ansi mesmo les comendaren algunas personas que tubiesen devoción [...] las quales pueda decir en esta santa iglesia en la capilla que se hiziere en la iglesia y en las demás iglesias parroquiales de esta ciudad siendo al voluntad de los que manden decir las dichas misas que sean dichas en esas iglesias.» ${ }^{85}$

Fue así como empezó a institucionalizar algunas capellanías laicales o mercenarias a través de las cuales dichas personas destinaban una parte de sus bienes a la manutención o congrua sustentación de su persona. A cambio, el Padre Huerta se comprometía a celebrar periódicamente cierto número de misas por el alma del fundador o de su familia. Las capellanías gozaban de importantes ventajas fiscales puesto que, como bienes eclesiásticos que eran, estaban exentas del pago del tributo. Sobre la naturaleza de los bienes que quedaban vinculados, lo más frecuente era dejar tierras o casas, aunque la mayoría de indios dejaban dinero, metales preciosos, o cualquier otro tipo de bien de valor ${ }^{86}$.

Éste, y no otro, fue el motivo real de la disputa que se interpuso ante el Deán y Provisor. La Cofradía de Copacabana estaba produciendo una extraordinaria cantidad de beneficios en concepto de limosnas por bautismos, misas, entierros, y demás sacramentos que se situaban fuera del control del Cabildo. Y ello reportó cuantiosos beneficios al Padre Huerta. A finales de 1595 adquirió a Nufrio Soles, repostero del Virrey García Hurtado de Mendoza, sesenta fanegadas de tierras junto

\footnotetext{
${ }^{83}$ Rodríguez Valencia (1957), tomo II, p. 315.

${ }^{84}$ AAL, «Papeles Importantes». Legajo $n^{\circ}$ III. Expediente $n^{\circ} 4$, folio 7.

${ }^{85}$ AAL, «Papeles Importantes» Legajo $n^{\circ}$ III. Expediente $n^{\circ} 4$, folio 6. Véase también García Irigoyen (1906), tomo I, p. 34.

${ }^{86}$ Manuel Teruel Gregorio de Tejada (1993).
} 
al pueblo de Carabaillo, hacienda que recibió el nombre de Copacabana en homenaje a su patrona y protectora ${ }^{87}$. No es de extrañar que el Deán Pedro Muñiz Arias así como los canónigos Cristóbal Sánchez de Renedo y Miguel de Salinas trataran por todos los medios de incorporar tan cuantiosas rentas al patrimonio de la iglesia «ilegalizando» al Padre Huerta. Exigían que les fueran restituidos todos los beneficios, limosnas y donaciones que el párroco les había defraudado. Pero éste se defendió presentando el 13 de febrero de 1595 el nombramiento de cura expedido cinco años antes por el Arzobispo y argumentando que «quien lleva el trabajo solicitud y cuidado que con ellos se tiene y padece consoles y serenos a diversas oras a causa de yr los a confesar quando estan enfermos y a partes remotas es justo que así mesmo lleve el aprovechamiento y comodidad del estipendio y limosna que se da por el entierro, pues lo es anexo a lo otro, atento a lo que es ${ }^{88}$. Sin embargo, los curas de la catedral continuaron denunciando las actividades del Padre Huerta, a quien siempre consideraron como un intruso en el privilegiado mundo de los prebendados del Cabildo catedralicio de Lima.

\section{EPÍLOGO}

En 1604, el Arzobispo Mogrovejo consiguió finalmente fundar en San Lázaro una vice-parroquia dependiente del curato de la catedral, alternándose los cuatro sacerdotes en el servicio espiritual. Ello supuso un serio revés para las aspiraciones del Padre Huerta de continuar ejerciendo como vicario de los indios de San Lázaro, aunque, a diferencia de las dignidades presentadas por el monarca en España, el Padre Huerta había dado sobradas pruebas de sus capacidades en Lima. El 26 de abril de 1602, la Audiencia de Lima reconocía la valía de Huerta como hombre docto y maestro de lenguas que predicaba en ambas lenguas, la española y la de los naturales, recomendándole como hombre benemérito para una plaza de canónigo de cualquiera de los cabildos catedralicios del Perú.

Para los indios, en cambio, el traslado supuso un triunfo en sus continuas demandas a las autoridades civiles y eclesiásticas. En 1606, poco después de la partida del Arzobispo Mogrovejo para su tercera y última Visita eclesiástica (16051606), algunos españoles y mestizos, como Don Miguel Jerónimo y Don Hernando Quispe, Mayordomo Mayor de la Cofradía, solicitaron la construcción del nuevo

${ }^{87}$ Esta hacienda no la conservó por mucho tiempo. En 1608, el presbítero vendió el fundo a Don Alonso de Villamediana. Archivo General de la Nación, Títulos de Propiedad, Cuaderno 644, cfr. María Rostworowski de Díez Canseco (1977), pp. 56-57.

${ }^{88}$ AAL, «Papeles Importantes». Legajo $n^{\circ}$ III. Expediente $n^{\circ} 4$, folio 18. El Tercer Concilio Limense de 1583 había prohibido expresamente que se llevara cosa alguna por entierros y sepulturas, ni tampoco por bautismos, casamientos o velaciones, bajo pena de pérdida del salario y excomunión. Sin embargo, el Padre Huerta los admitía por producirse «de forma voluntaria». 
santuario y parroquia de Nuestra Señora de Copacabana, con su cofradía de indios, en el asentamiento de San Lázaro ${ }^{89}$. Con ello se pretendía atraer las limosnas de los fieles con el aliciente de alojar en la iglesia a la Virgen milagrosa. Toribio murió en la mañana del 23 de marzo de 1606 en Saña Grande, a noventa leguas de Lima, en olor de santidad. En agosto de 1606, Doña Grimanesa, su hermana, solicitó al Cabildo de Lima el traslado de sus restos a la Catedral para enterrarlo. En septiembre de 1607 se trasladó su cuerpo en un trayecto de 590 kilómetros que duró ochenta días. Le acompañaba un cortejo fúnebre integrado por el maestrescuela, Don Mateo González de Paz, doce sacerdotes y miles de indios ${ }^{90}$. «Santo Toribio», como le llamaban, se había ido y los indios esperaban que la Madona los protegiera de todos los males ${ }^{91}$. También esperaban que los protegiera de las campañas de extirpación de idolatrías acordadas en 1610 por el jesuita Pablo José de Arriaga (1563-1622), Rector del Colegio de San Martín, el tercer arzobispo de Lima, el jesuita Bartolomé Lobo Guerrero (1609-1622), que había sido fiscal en la Inquisición de México, y el Virrey-poeta Juan de Mendoza y Luna, Marqués de Montesclaros (1607-1615). Esta actitud represiva se consolidó en el Sínodo de Lima de 1613 (artículo 8), en el que se prohibía la mayor parte de bailes, fiestas y ceremonias nativas en todo el Perú central, y sobre todo en el arzobispado de Lima ${ }^{92}$. No hay duda de que Toribio siempre fue consciente de la pervivencia de dichas «idolatrías» en el Virreinato peruano. Pero, como señala Mary M. McGlone, «[he] understood it as a problem of poor evangelization rather than an offense to be forcibly extirpated $»^{93}$.

Tras muchas deliberaciones, Lobo Guerrero autorizó en 1615 el traslado de la imagen, pero el Cabildo eclesiástico se opuso aduciendo que «era de muy humilde fábrica». En 1617 se hizo efectivo dicho traslado y, según León Pinelo, «dispusose la obra con limosnas de los Indios; y arrimada a la Iglesia, se hizo casa para un sacerdote, que la tuviese a su cargo, y dijese misa cada día, disponiéndolo el arzobispo D. Bartolomé Lobo Guerrero» ${ }^{94}$. Por aquel entonces, en 1616, el Padre Huerta publicó una gramática quechua: el Arte de la lengva qvechua de

\footnotetext{
${ }^{89}$ Vargas Ugarte (1959), tomo II, p. 499. En el Archivo Arzobispal de Lima se conserva el auto de procesamiento contra Don Pedro de la Cruz y Don Miguel Sánchez de la Peaza, antiguo Mayordomo de la Cofradía de Nuestra Señora de Copacabana, por irregularidades en las cuentas. AAL, Sección Cofradías, Legajo X: 1, 1604, 4 folios.

90 Benito Rodríguez (1995), p. 28.

${ }^{91}$ León Pinelo (1653), pp. 277-281. En 1607, las crecidas del Rímac habían derribado definitivamente el puente de cal y ladrillo que levantó el Marqués de Cañete entre 1557 y 1560: véase A. San Cristóbal (1984), pp. 31-50. El 19 de octubre de 1609, los temblores destruyeron más de 500 casas y ocasionaron considerables perdidas en la ciudad: vid. Pedro de León Portocarrero (1958) [c. 1610] p. 75, y Pedro de Oña (1609).

92 B. Lobo Guerrero y F. Arias de Ugarte (1987).

${ }^{93}$ McGlone (1991), pp. 252.

${ }^{94}$ León Pinelo (1653), p. 120.
} 
los Yndios de este Reyno del Piru ${ }^{95}$, cuyo objetivo principal era presentar un manual que fuera útil para todos aquellos que quisieran aprender la lengua de los naturales. Se leyó el 30 de septiembre de 1615 ante el Arzobispo de Lima, Don Bartolomé Lobo Guerrero (1599-1609), y recibió licencia de impresión del marqués de Montesclaros, Virrey del Perú, el 5 de octubre de $1615^{96}$.

Al final, después de muchas deliberaciones, los indios de San Lázaro se salieron con la suya ${ }^{97}$. Mientras tenía lugar el proceso de beatificación de Toribio de Mogrovejo, iniciado entre 1631 y 1632 a petición del Cabildo eclesiástico de Lima ${ }^{98}$, la Virgen fue conducida en solemne procesión por la Cofradía a través de la Alameda de los Descalzos hacia su santuario el 28 de diciembre de 1633, día del $42^{\circ}$ aniversario del milagro que tuvo lugar en la parroquia del Cercado (28/12/1591), asistiendo el quinto arzobispo de Lima, Don Fernando Arias de Ugarte (1630-1638), y el Virrey Conde de Chinchón ${ }^{99}$.

Fueron años de reencuentros. Por un lado, los indios recuperaron su imagen y trasladaron la Cofradía de Nuestra Señora de Copacabana de la Catedral al barrio de San Lázaro. Por otro, el Padre Huerta se reencontró con los jesuitas. Parece que, algunos años antes, el Padre Huerta había fundado un colegio de padres agustinos junto a su misma casa. Después tuvo algunos desencuentros con ellos, y al final de sus días cedió a la Compañía todos sus bienes. En las Cartas Anuas de la Provincia del Perú de los años 1639 y 1640 se hace mención de doce pares de esclavos y chácaras, cuyo valor ascendía a unos cuarenta mil pesos. En su testamento, dictado en Lima el 7 de junio de 1639 ante el escribano Don Diego Jaramillo, dispuso que con parte de los mismos se fijase una renta de 400 pesos anuales para el sostenimiento de las misiones y pidió que se le reconociera como bienhechor insigne del Colegio Máximo de San Pablo, pues la donación vino a

${ }^{95}$ Lima: Francisco del Canto. Vid. Enrique Torres Saldamando (año).

${ }^{96}$ José Toribio Medina Polo (1965) [1904], tomo I, p. 142.

${ }^{97}$ Ibidem. El maestro Huerta testó el 7 de junio de 1639 ante el escribano Diego Jaramillo. Participó como testigo en el proceso de beatificación del arzobispo Mogrovejo y murió a primeros de abril de 1640, siete años después del traslado final de la Virgen de Copacabana al barrio de San Lázaro.

${ }_{98}$ El Padre Huerta fue el autor de un detallado informe de la vida y virtudes del arzobispo Mogrovejo (Lima, 10 de noviembre de 1631). Dicho informe, junto con los de otros testigos, fue presentado en la Curia Romana, conformando los folios 276-288. León Pinelo (1653), p. 345. Asimismo, el canónigo del Cabildo catedralicio, Don Bartolomé Menacho (1548-1640), fue uno de los que subscribió la solicitud dirigida al Arzobispo de Lima, Fernando Arias de Ugarte, para que se hicieran los informes sobre la vida de Toribio de Mogrovejo. En el Archivo Arzobispal de Lima existen 16 legajos que contienen las actas del proceso de beatificación de Toribio de Mogrovejo. De todo el proceso se hizo un compendio en el Sumario y memorial ajustado de las probanzas que por deposiciones de testigos e instrumentos se han hecho por el ISD D. Pedro de Villagómez, arzobispo de los Reyes y demás Señores Jueces Apostólicos en la Causa de la Beatificación y Canonización del Siervo de Dios el IS Don Toribio Alfonso Mogrovejo, arzobispo que fue desta ciudad. (1662): Lima: Imprenta de Juan de Quevedo y Zárate.

${ }^{99}$ León Pinelo (1653), p. 120; Vargas Ugarte (1956), pp. 182-190. 
parar a esta casa. El Padre Mastrilli Durán lo reconoció como bienhechor con derecho a ser enterrado en la bóveda principal de la iglesia de San Pablo, y su albacea, Don Francisco de León, poco después de la muerte del maestro Huerta en 1640, pidió que se le dijeran las misas prescritas y que se le admitiera el patronazgo $^{100}$.

\section{FUENTES:}

Archivo Arzobispal de Lima (AAL). Lima.

Archivo Capitular (o del Cabildo Eclesiástico) de Lima (ACL). Lima.

Archivum Romanum Societatis Iesu (ARSI). Roma.

\section{BIBLIOGRAFÍA:}

Angulo, D., OP. (1971): «Nuestra Señora de Copacabana». Revista Histórica (Lima) 5, Entrega III, pp. 323-325.

Benito Rodríguez, J. A. (1995): El castellano-leonés que abrazó todas las razas: Santo Toribio de Mogrovejo, Valladolid: Junta de Castilla y León.

Bromley, J. y BARBAgELATA, J. (1945): Evolución urbana de Lima. Lima: Talleres Lumen.

Coello DE la Rosa, A. (inédito): «Espacios de exclusión, espacios de poder: la reducción de Santiago del Cercado en Lima colonial (1568-1606)».

Dussel, E.D. (1969): El episcopado americano. México: Cidoc, Sondeos.

- (1983): Historia General de la Iglesia en América Latina, Tomo I/1. Introducción General a la Historia de la Iglesia en América Latina, Salamanca: CEHILA, Ediciones Sígueme.

Dammert Bellido, J. (1996): El clero diocesano en el Perú del siglo xvi. Cuzco: Instituto Bartolomé de Las Casas y Centro de Estudios y Publicaciones.

Echave y Assu, F. DE (1688): La estrella de Lima convertida en sol sobre sus tres coronas. El B. Toribio Alfonso Mogrobexo, su segundo arzobispo, Amberes: Juan Baptista Verdussen.

Egaña, A. DE, SJ (1966-70): Monumenta Peruana. Roma: Borgo Santo Spirito, Archivum Historicum Societatis Iesu (ARSI), tomos IV y V.

Fox, K. V. (1962): «Pedro Muñiz, Dean of Lima, and the Indian Labor Question (1603)». The Hispanic American Historical Review 42 (n $\left.{ }^{\circ} 1\right)$, pp. 63-88.

García Irigoyen, C. (1906): Santo Toribio. Lima: Librería de San Pedro.

Guibovich Pérez, P. (1994): «Mal obispo o mártir. El obispo Mollinedo y el Cabildo eclesiástico del Cuzco, 1673-1699», en G. Ramos (comp.), La venida del reino. Religión, evangelización y cultura en América. Siglos XVI-XX. Cuzco: Centro de Estudios Regionales Andinos «Bartolomé de Las Casas», pp. 151-173.

${ }^{100}$ ARSI, Peruana Litterae Annuae, Tomo IV (1630-1651), pp. 160 y 160v. Véase también los trabajos de Medina Polo (1965), pp. 142, y Vargas Ugarte (1963), p. 119. 
Haroldo, F. (1680): Beati Thuribii Alphonsi Mogroveii, Archiepiscopi limensis, eita exemplaris. Roma.

Huerta, Alonso de (1616): Arte de la lengva quechua de los Yndios de este Reyno del Piru. Lima: Francisco del Canto.

León Pinelo, A. De (1653): Vida del Ilustrísimo y Reverendísimo D. Toribio Alfonso de Mogrovejo, Arzobispo de la ciudad de Los Reyes, Madrid.

León Portocarrero, P. De (1958) [c. 1610]: Descripción del Virreinato del Perú. Crónica inédita de comienzos del siglo XVII. Edición de B. Lewin. Rosario: Universidad Nacional del Litoral, Instituto de Investigaciones Históricas. Colección de textos y documentos, Serie B, $\mathrm{n}^{\circ} 1$.

Levillier, R. (1926): Gobernantes del Perú. Cartas y Papeles. Madrid: Sucesores de Rivadeneyra, Tomo XIV.

Lissón Chaves, E. (1944-1945): Colección de documentos para la historia de la Iglesia en el Perú, que se encuentran en varios archivos. Sevilla: Editorial Católica.

Lobo Guerrero, B. y Arias de Ugarte, F. (1987): Sínodos de Lima de 1613 a 1636. Madrid: CSIC, Sínodos Americanos, $\mathrm{n}^{\circ} 6$.

Lohmann Villena, G. (1949): Las minas de Huancavélica en los siglos XVI y XVII, Sevilla: CSIC.

- (1992): «Santo Toribio, el limosnero». Boletín del Instituto Riva-Agüero, Pontificia Universidad Católica del Perú no 19, pp. 65-78.

Lorea, A. DE (1679): El Bienaventurado Toribio Alfonso Mogrovejo. Madrid.

McGlone, M. M. (1991): The Lost Opportunity: Santo Toribio de Mogrovejo and the Beginnings of the Church in Peru. Ph. D. Dissertation, Saint Louis University.

Maravall, J. A. (1972): Estado moderno y mentalidad social. Siglos XI a XVII. Madrid: Alianza Editorial, Tomo I.

(1975): La cultura del Barroco, Madrid: Editorial Ariel.

Martini, M. P. (1988): «Dificultades en la administración de sacramentos a los indios. Legislación canónica en el territorio de la primitiva arquidiócesis limense». Revista de Historia del Derecho. Buenos Aires: Instituto de Investigaciones de Historia del Derecho (ed.), $n^{\circ} 16$, pp. 331-389.

- (1991): «Los Sínodos de Toribio de Mogrovejo (1582-1604). Entre la legislación conciliar y la realidad americana». Actas del IX Congreso del Instituto Internacional de Historia del Derecho Indiano. Madrid, Editorial de la Universidad Complutense, tomo II, pp. 461-487.

Medina Polo, T. J. (1965) [1904]: La Imprenta en Lima (1584-1824). Amsterdam: N. Israel, tomo I.

Mendiburu, M. DE (1885): Diccionario histórico-biográfico del Perú. Lima: Imprenta de Juan Francisco Solís, Tomo V.

Numhauser Bar-Magen, P. (2005): Mujeres indias y señores de la coca. Potosí y Cuzco en el siglo XVI. Madrid: Cátedra.

OÑa, P. DE (1609): Los temblores de Lima. Lima: Francisco del Canto.

Ramírez, B. [1597]: «Descripción del reyno del Pirú», en V. M. Maurtúa (1906), Juicio de Límites entre Perú y Bolivia. Tomo I, Virreinato Peruano. Barcelona: Imprenta de Henrich y Compañía.

Rodríguez Valencia, V. (1948a): «Más luz sobre el supuesto Memorial del Santo al Papa Clemente viII». Missionalia Hispanica V, nº 13, pp. 137-208. 
- (1948b): «Santo Toribio de Mogrovejo, punto de equilibrio entre la Santa Sede y el Regio Patronato español de Indias». Missionalia Hispanica V, n 13, pp. 1-137.

- (1957): Santo Toribio de Mogrovejo. Organizador y Apóstol de Sur-América. Madrid: CSIC, tomo II.

Rostworowski de Díez Canseco, M. (1977): Etnia y sociedad. Costa peruana prehispánica, Lima: IEP.

San Cristóbal, A. (1984): «Los puentes de Lima de 1607 y 1608». Historia y Cultura. Revista del Museo Nacional de Historia ${ }^{\circ}$ 17, pp. 31-50.

Sumario y memorial ajustado de las probanzas que por deposiciones de testigos e instrumentos se han hecho por el ISD D. Pedro de Villagómez, arzobispo de los Reyes y demás Señores Jueces Apostólicos en la Causa de la Beatificación y Canonización del Siervo de Dios el IS Don Toribio Alfonso Mogrovejo, arzobispo que fue desta ciudad (1662): Lima: Imprenta de Juan de Quevedo y Zárate.

Teruel Gregorio de Tejada, M. (1993): Vocabulario básico de Historia de la Iglesia, Barcelona: Editorial Crítica.

Torres Saldamando, E. ( ): «Don Alonso de Huerta y su Gramática quechua». Revista Social de Lima.

Vargas Ugarte, R., SJ (1959): Historia de la Iglesia en el Perú. Burgos: Imprenta de Aldecoa.

- (1963): Historia de la Compañía de Jesús en el Perú. Burgos: Aldecoa, tomo II.

- (1971): Vida de Santo Toribio. Lima.

Үвот León, A. (1962): La Iglesia y los eclesiásticos españoles en la empresa de Indias. Barcelona: Salvat Editores. Tomo XVII.

\section{APÉNDICE DOCUMENTAL}

«Nombramiento de cura a favor del maestro Alonso Huerta» ${ }^{101}$.

Nos, don Toribio Alfonso Mogrovejo, por la miseración divina y de la Santa Iglesia de Roma, Arzobispo de los Reyes, del Consejo de su Majestad, etc. Por la presente: confiando de las buenas partes, habilidad y suficiencia, letras y cristiandad de vos el Maestro Alonso de Huerta, os damos licencia para que en el interin que se provee la doctrina del Cercado, por la orden del Real patronazgo y después de proveída en vos podáis administrar y administréis los Santos Sacramentos, así el del matrimonio como los demás, á todos los indios de las doctrinas del Cercado y sus anexos, así de los que se han reducido de la parroquia de San Lázaro al dicho Cercado y de esta ciudad, como de otras cualquier tiempo pasado, y á los que se redujeren y vivieren ó habitaren y estuvieren en las dichas doctrinas del Cercado, así poblados en la doctrina de los padres de la Compañía de Jesús, como en la que ahora de nuevo se ha hecho y está á vuestro cargo, y hacer en todo el

\footnotetext{
${ }^{101}$ Cfr. García Irigoyen (1906), tomo II, pp.185-188.
} 
oficio de cura, y de tal manera que los dichos indios de San Lázaro y los demás que se han reducido y redujeren de esta ciudad en la nueva reducción, y por orden del señor Virrey Don García de Mendoza se ha hecho, y á los que vinieren de otras partes y doctrinas á venir ó estar en el dicho Cercado, por el dicho maestro Huerta les podáis administrar y administréis los dichos Santos Sacramentos del matrimonio y los demás, y no otro sacerdote alguno, clérigo ó religioso, aunque sea de los de la Compañía de Jesús, sin expresa licencia nuestra in scriptis ó del dicho maestro Huerta, no obstante otras cualesquier licencias nuestras ó de nuestros predecesores y Provisores y sede vacantes; y os damos asimismo la dicha licencia, para que podáis administrar los Santos Sacramentos del matrimonio y los demás Sacramentos á todos los indios que están y estuvieren de aquí adelante en esta ciudad y sus arrabales, guardando en todo lo proveído por constituciones de este arzobispado y SantoConcilio de Trento, en especial en lo ordenado en sesión 29, capítulo 7 de reformación matrimonial que trata de los vagantes, y de los que tienen posadas que trata de los vagantes, y de los que tienen posadas inciertas, haciendo en el tal caso cerca de los tales, diligente inquisición primero, y remitiéndola al Ordinario, y pidiendo y obteniendo licencia del tal Ordinario, y pidiendo y obteniendo licencia del tal Ordinario para hacer algún casamiento; y para que de lo susodicho, los padres de la Compañía de Jesús, no pretendan ignorancia, mandamos se dé noticias del dicho nombramiento de cura, así al Presente Rector de la Compañía, como al cura que en la dicha doctrina estuviere, y pidiéndoles de nuestra parte exhiban las licencias y presentaciones que tuvieren para poder hacer el oficio de curas en la dicha doctrina del Cercado, y advirtiéndoles que no se dará lugar en manera alguna á que administren los Santos Sacramentos, y que es nuestra determinada voluntad, que no teniendo las dichas licencias que de aquí adelante por nos, ó por el dicho maestro Huerta, se les diere, no puedan administrar los dichos Sacramentos, en conformidad de lo proveído por el Santo Concilio de Trento, y declaración de los ilustrísimos señores Cardenales, intérpretes del Santo Concilio de Trento, satisfaciendo á la duda por nos consultada y carta á nos escrita por el ilustrísimo señor Cardenal Carrapha, como presidente de la congregación de los dichos señores Cardenales, firmada con su firma y sellada con su sello.

La cual dicha licencia y lo demás de suso referido, damos y proveemos y ordenamos por la vía que más conviene, podemos y ha lugar de derecho, de manera que en todo l oque se hiciere se descargue la conciencia y Nuestro Señor se sirva; y asimismo, demás de lo que está referido atendiendo á la cédula de su Majestad en conformidad de lo susodicho que es el tenor siguiente: «Nuestro Virrey de las Provincias del Perú, por algunas presentaciones de beneficios y doctrinas que vos habéis dado en esas provincias á clérigos y frailes que se han visto en el nuestro Consejo de las Indias ha parecido que en las dichas presentaciones ponéis dos cláusulas: la una en la que dáis á frailes que dice, que el fraile presentado 
use del propio motu que su orden tiene si el Obispo ó su vicario en virtud de la presentación no le diere licencia para servir el beneficio ó doctrina; y la otra que si el sacerdote proveído hubiere estado sirviendo el beneficio ó doctrina en que le presentáis antes que tenga la presentación no se le pague salario del tiempo que hubiere servido, sin la tal presentación. Y porque por algunas causas ha parecido que es de mucho daño é inconveniente al servicio de nuestro Señor y las almas de los vecinos y naturales de Provincias el ponerse las dichas cláusulas en las dichas presentaciones os mandamos que en las que de aquí adelante diciéredes, no pongáis las dichas cláusulas en manera alguna y procuráis que se pague el salario del tiempo que el sacerdote hubiere servido el beneficio ó doctrina por encomienda, avisando el Prelado de la vacante dentro de cuarenta días, lo cual hará el tal Prelado á costa de los frutos del beneficio ó doctrina que vacare ó se hubiere de proveer. Fecha en Badajoz, a cinco de agosto de mil quinientos ochenta. Yo el Rey. - Por mandato de su Majestad.- Antonio Eraso.

De lo cual mandamos dar y dimos la presente firmada de nuestro nombre, sellado con nuestro sello, refrendado de nuestro secretario, dada en la ciudad de los Reyes, á tres de diciembre de mil quinientos noventa. Vale gratis.

Thuribius Archiepiscopus de los Reyes.

Por mandado de su Señoría Ilustrísima.- Alonso Ramírez Berrio. Secretario. Gratis. 
